\title{
Corruption as Legal Consciousness Transformation (Social-Philosophic Aspect)
}

\author{
Stanislav V. Kuz ** \\ Siberian Federal University \\ 79 Svobodny, Krasnoyarsk, 660041, Russia
}

Received 13.01.2015, received in revised form 19.03.2015, accepted 16.05.2015

\begin{abstract}
The urgency of the present article is connected to the fact that, starting to threat the security of the country, corruption is becoming a major problem in more than just legal context. The author proves that the research of corruption origin is impossible without consideration of the social-philosophic factor.

The article reveals the social-philosophic origins of corrupt practices. The author pays special attention to the peculiarities of corrupt consciousness in Russia. He proves that such antisocial deeds are mainly caused by the transformation of legal awareness which has been a historical process happening in Russia. Along with that, the article demonstrates the ways to decrease the problem of corruption which is, to a large extent, determined by legal acculturation of Russian citizens.

The article emphasizes the fact that for efficient corruption therapy on the highest level of legal technique, the law must be steadily and accurately observed, as any law is sustainable only if observed by everyone and everywhere. That is why even stand-alone cases of corruption discredit the concept of the state of law itself.

Corruption is also determined by the fact that the specificity of the connection between each form of social consciousness and the law does not mean the absence of any common ways and methods of interaction, which would give us a reason to stipulate the correlation of social consciousness as a unity of multiple forms to the law and legal order.

In the analysis of peculiarities of corrupt thinking and behaviour in our country the principal role is played by the discussion about the types of society, intended to reveal the reasons for finding theorizing specificity for each social type. The necessity for outlining types of society and distinguishing between them is also determined by social practice, when modern Russian reality is being imposed the dominating spiritual and social values proven positive in the Western life, with the neglect and diminution of its proprietary social experience.

Studying the corruption issues one should remember that interaction of an individual with a new social medium happens only with support of their existing knowledge and previous experience of social and legal behaviour. This process is accompanied by the continuous analysis of the new social demands, comparison of the new demands to the previous concepts and mindsets. In its content, legal consciousness of an individual may be on the same dimension level with that of the collective, but may be significantly different.

The only real counteraction against corruption is a healthy everyday life of a collective of individuals, filled with great spiritual sense and positive social intentions. It is explained by the fact that a society can successfully perform its positive incentive function to make an impact on the legal consciousness of its members, shaping a firm social and legal position in their minds.
\end{abstract}

(C) Siberian Federal University. All rights reserved

* Corresponding author E-mail address: decanka@mail.ru 
The author arrives at the conclusion that the presence of appropriate social conditions may act as the basis for both corrupt consciousness formation and counteraction against it, creation of an uncompromising anticorruption climate, thereby forming new relationships within the corruptionproof generation.

Keywords: corruption, legal consciousness, legal consciousness transformation, social life institutionalization, social control, civil society.

Research area: philosophy.

The urgency of studying social-philosophic aspects of corruption is determined by a number of reasons. First of all, the character of relations between the state and personality, the position of a Russian citizen are dramatically changing. The citizen has acquired the capacity to fulfil their potential as a free personality able to influence the war on corruption in the country. Secondly, the establishment and development of market relations brings the necessity to develop such essential personal features as agility and business-like manners, which in certain cases tempts people to accelerate the resolution of their personal issues by means of corruption. Thirdly, the level and intention of the state population's legal consciousness is the fundamental factor the legal order relies on. Having laws of the highest level of legal technique is not enough; the important thing is steady and sustainable observation of the laws. A law is sustainable only when observed by everyone and everywhere. That is why even stand-alone cases of corruption discredit the concept of the state of law itself.

Resolution of the corruption problem assumes integrated efforts of political experts, sociologists, psychologists and specialists of other fields of study. The dominating works to be relied on are those of economists and lawyers, but in our opinion, modern Russian political elite seem to underestimate the fact of corruption being a social-philosophic phenomenon. It is connected to the dynamic transformations, the structural reconstruction of the whole system of social relations and social consciousness happening in modern Russia and other former Soviet countries. Among the problems studied by modern experts in philosophy, theory of right, sociology and psychology a special place is occupied by the concept of legal awareness. As we can see, the problem of corruption is tightly connected to the problem of establishment and development of legal consciousness which, in its turn, assumes active formation of a state of law. As we know, one of the basic conditions of the state of law is a high intellectual level of the society, its political and legal culture. Successful development of the people's legal consciousness mostly depends on the right theoretical understanding and philosophic underpinning of the fundamental legal categories. For many years the theory of law had been blindly following the official Marxist ideology instead of leading its course; for this reason, many legal problems used to be solved in the spirit of the existing political regime, which never facilitated the development of the people's legal thinking or realization of their rights.

Successful resolution of the corruption problem is only possible on the basis of socialphilosophic analysis, reviewing all the basic theoretic legal axioms. For the current topic such axioms are, first of all, the problems of legal awareness determining the core principles of the underlying legal categories in the context of civilian and political values. A fully developed civil society can only develop provided that the state apparatus functions are limited and the mistrust between different social groups is overcome. 
The increasing impact of social factors on the social progress determine the relevance of studying the factors themselves, the conditions of their emergence, existence, development, and forms of influencing various sorts of social relations. Corrupt thinking is one of the social factors influencing the society as a single functioning organism and, therefore, its legal awareness. Corruption therapy is an activity relevant in multiple spheres of human life, as resolution of this problem is extremely important for the development of personality, civil society and various social relations. Moreover, the level of corruption and fight against it can make an impact on different forms of social awareness: economic, moral, political etc.

In his book "On Aggression” Konrad Lorenz suggests that both a human and an animal have a reserve of aggressive energy seeking release, which can be easily discharged in the situation of competition and detected threat. In this aspect a human being acts like other species of the animal kingdom, the survival of which depends on such instinct. By means of "natural selection" process (more aggressive ones are more likely to survive, find a partner and pass on their aggressive features to their posteriors) the evolutionary process could probably simulate the development of people with higher intellect and inclination to fight. The hypothesis of the survival of the aggressive is followed by the thesis of Edward O. Wilson, according to which human beings are strongly predisposed to respond with unreasoning hatred to external threat to their security or property. That is the "underlying predisposition of human beings to violence", Wilson claims. "Our brains do appear to be programmed to the following extent: we are inclined to partition other people into friend and aliens...We tend to fear deeply the actions of strangers and to solve conflicts by aggression". He suggests that "these learning rules are most likely to have evolved during the past hundreds or thousands of years of human evolution and, thus, to have conferred a biological advantage on those who conformed to them with the greatest fidelity" [7, p. 20].

The establishment of anti-corruption awareness and its specificity are determined by the system of social relations that has been formed by the national traditions throughout the entire history of its existence and development. Moreover, there are some internal factors, such as psychological characteristics and peculiarities of an individual and mentality of each person. For instance, for the conformist-negative Russian legal awareness the typical features are ethicscentrism and nihilism. The fact that many of the features provoking potential corruption are mostly successive, complicates the process of corruption therapy due to its seeming inviolability: there are examples of corrupt behaviour presented as normal in all classic works of literature and fairytales.

The corruption therapy process requires transformation of today's legal consciousness and is dialectically interconnected with the process of civil society establishment. In this aspect, it is impossible to hope for successful resolution of the corruption therapy tasks without formation of the correct legal consciousness for the entire population without clear philosophic concept of the nature, structure and functions of the legal consciousness, its interconnection with other ideological phenomena, tendencies of its formation and development. "It is impossible for a person not to be legally aware; it is a must for everyone who knows that there are other people living in this world" [2, p. 115].

If corruption is admitted to be a part of our traditional culture, the state bodies are being guided by their legal discretions. Moreover, it would recognize all claims of people, based not only on the major legal positions, but also all other claims as legal. In this case, legal awareness may 
be equal to zero or even be negative $[12$, p. 104116].

Itpreconditions the peculiarities of corruption therapy in our country. A famous Russian philosopher and legal expert V.S. Nersesiants [10] is convinced that it is the form of realizing law as a specific phenomenon of social reality. Its main functions are: cognitive (realization of what law is in sensual, imagery, logical and conceptual forms of revelation, expression and apprehension of legal phenomenon and law as a whole); evaluative (forming certain axiological ideas and concepts of the law, relying on which the legally aware individual evaluates the current law and present legal reality); regulative (formed under the impact of the other functions). Studying corruption as a phenomenon, V.S. Nersesiants [11] remarks that legal awareness is more than awareness of law; it is also legal self-consciousness, self-awareness within the legal framework, determination of the person's own role and place in the world of law, selection of a legal role, legally significant objectives and actions. Work of legal awareness is a continuous sensual and mental experiment on testing and re-testing of legal awareness for different legally significant models and variant of behaviour in the surrounding world. Specificity of legal awareness is determined by its correlation with the other forms of awareness (moral, ethic, religious awareness etc.).

Before deployment of efficient corruption therapy as a functioning action, we should study the nature of legal awareness and its interconnection with the law, produce a general definition of legal awareness. The works published in the recent years witness the emergence of these issues in many researches over and over again, the diversity of definitions provided for legal awareness, from absolute identification of law and legal awareness and to the radical separation and opposition of the two phenomena. The diapason of understanding awareness of law is just as wide and diverse. There is a huge variety of opinions that proves the complexity of the problem.

A person has a right to live in a corruptionfree society, as corrupt reality manifests a sort of legal tragicomedy when ugly, warped legal perception remains to distort its concept even more; it addresses the idea of law but adopts nothing but its pattern, uses it in its own wicked way, abuses it, filling it with indecent, perverse content. It brings up the "wrong law" which, nevertheless, bears the name of "law" and is claimed to be one, discrediting the idea of law in the people's minds, undermining the faith in law as such. This tragicomedy is typical for more than just legal awareness: it is the tragicomedy of the whole spiritual life of people [11].

Modern Russia is living through a series of metamorphoses in all spheres of its life; it inevitably leads to a set of transformations both in the social and political life of the country, and within the consciousness of every person. We are witnessing the conditions that cause dramatic changes to the character of relations between the state and personality, to the position of a Russian citizen, who acquire an opportunity to realize their potential as a free personality able to participate in their country's war on corruption.

The establishment and development of market relations brings the necessity of developing such essential personal features as agility and businesslike manners, which in certain cases tempts people to accelerate the resolution of personal issues by means of corruption. But it is the level and the character of the legal awareness of the population as a whole, of separate groups and citizens, the corrupt component in the nonlegal activity of citizens depends on. Having laws of the highest level of legal technique is not enough; the important thing is steady and sustainable observation of the laws. A law is sustainable only when observed by everyone and 
everywhere. That is why even stand-alone cases of corruption discredit the concept of the state of law itself.

Outlining the peculiarities of corruption motivation, it is important to consider that there are collisions of interests, mindsets, different targets and wills that happen in the process of such interaction. There is no society that could exist without regulating individuals' behaviour in all spheres of their lives and deeds; it would be impossible without a system of standards and institutes established in the society. Such institutionalization of social life is a way of social control over the activities of the society members, depriving potential corruption of its basis. It is clear that Russian community just like any other society is manifested through interaction of individuals, bigger and smaller groups, thereby suggesting a special methodology for the present research.

Impartial study of the origins and peculiarities of corruption is based on the fact that social relations between people are their social activity in the process of production, transformation of nature, organization of conditions for everyday life, along with the stable bonds between people, a stand-alone person and the real world. In the process of production it is not only nature people interact with. They cannot produce any commodity without uniting into groups for joint activity and experience exchange. In order to produce a commodity, people enter certain relations and connections, and their relation with nature, the process of production itself only exists within the framework of such relations and connections. "The problem of consciousness, its purpose and functioning is one of the major ones for any social science. No matter what issue gets in the focus of such a science, it is primarily addressed to the essence of a human being and personality as the actor of social and historical processes" [8, p. 48].
Characteristic of corruption is determined by the fact that, unlike legal awareness, the law exists not only as a unity of different forms of law (civil, labour, administrative, constitutional, criminal etc.) established in the legislation, but also as a certain system of legal relations. Corruption is also determined by the fact that specificity of bonds between the law and each form of social awareness never means the absence of common ways or ways of interaction, which leads us to the idea of a correlation of social consciousness in the unity of its forms with the law and justice.

1. Corruption reflects only those phenomena that compose that legal aspect of social life. It includes the process of establishing principles of law and implementation of their requirements in social life. Political, ethical, other ideas and concepts also make a strong impact on formulation and implementation of principles of law. But before they find their incarnation in the principles of law, these ideas and concepts must be processed through legal awareness, which means, they must acquire their legal shape as legal ideas and concepts.

2. Another peculiarity of corruption is the way it reflects the social life phenomena. Awareness of legal phenomena of the social life is provided by a set of special legal terms and categories. Among them there are such terms as legitimacy, non-legitimacy, legal relations, legal responsibility, and justice. At the same time, moral consciousness evaluates the world with the set of its own terms: good, evil, fair, unfair, honour and dignity.

3. Corruption makes an impact on personality and social relations; however, it should be noted that the result of the regulative function is the behavioural response of the subject of law in the form of legitimate or delinquent behaviour [6].

The modern globalizing world forces many researchers to review their opinion on the world 
economy as a whole and the origins of corruption as such due to the new emerging tendencies.

First of all, the concepts, claiming the necessity to apply Christian measures to economic science without losing the scientific and research methodology, look more and more sustainable. Secondly, the more profound approach to the established economic "truths" proved by facts and mere logic may bring out new explanations of corrupt behaviour. Crisis happens only when history attempts to make general conclusions on the whole nation, filled with mercenary claims, unscrupulous vagrancy and helpless explosions.

Having acquired some knowledge and professional skills, a person begins to take active participation in the social system as a member of a certain social group, class, labour collective, social or political association, property owner, manufacturer of material or spiritual goods; in other words, the person takes part in a certain sphere of social being. It concerns both legal and corrupt activity.

The dominating role in evaluation of such social transformations as corruption is still played by civilizational approach. The civilizational approach, actively and generally applied to universal law interpretation, does not account for the peculiarities of every social sphere depending on the type of society in question. Together with that, very often it does not account for the legal experience of the Western civilization derived from suffering of other countries' people, which could be useful in Russian life and its legislation.

In the analysis of peculiarities of corrupt thinking and behaviour in our country the principal role is played by the discussion about the types of society, intended to reveal the reasons for finding theorizing specificity for each social type. The necessity for outlining types of society and distinguishing between them is also determined by social practice, when modern Russian reality is being imposed the dominating spiritual and social values proven positive in the Western life, with the neglect and diminution of its proprietary social experience. Such situation can be observed at the formulation of basic concepts of socialphilosophic theories, including the theory of legal awareness. It is natural that the type of society makes a principal impact on the level of corrupt consciousness which depends on the traditions of the society and peculiarities of relations between different bodies of state authorities. This is the level creating the grounds for corruption in any country, let alone Russia.

Analysing peculiarities of corrupt practices in each type of society, we should remark that an individualist society has its own distinctive variant of "harmony" different from that of a collectivist society. In an individualist society any action or omission of its member is predetermined by some behaviour regulations contained in legal standards. In a collectivist society the dominating number of issues is solved with such social standards as moral and ethical standards, religious norms, norms of customs, traditions etc. That is why an individualist society is a steady "social mechanism", though not guaranteed against any failures, while a collectivist society is a "social organism" which is healthy only when the existing norms meet the social requirements, and which is ill when imposed any "alien bodies", adopted social phenomena untypical of this very type of society. Such peculiarities gain special importance in the context of the present research, as corruptions leads to the decrease of state institutions' efficiency and, therefore, to the degradation of the society itself.

An important motive of corruption is literal understanding of the freedom of will. As interests of people in an individualist society are different, reaching consensus under such conditions would bring equality of rights and equality in restriction of such rights. However, evaluation of legal 
norms carried out by each representative of an individualist society usually relies on fulfilling the freedom of will principle of the legislators and law enforcers and the freedom of will of those whose freedom is restricted by the legislative acts. The non-legal norms are evaluated as positive or negative depending on whether they conform to the law or not. Negative evaluation leads to a correction, clarification or criticism of such social norms [9].

Studying corruption, one should remember that interaction of an individual with a new social medium happens onlywith support of their existing knowledge and previous experience of social and legal behaviour. This process is accompanied with continuous analysis of the new social demands, comparison of the new demands with the previous concepts and mindsets. In its content, the legal consciousness of an individual may be on the same level with that of the collective, but may be significantly different. This point usually serves as a ground for collision of interests, objectives and system of values of the individual with the ideas and social legal demands dominating in the society. The contradiction is usually overcome in the process of interaction between the individual legal awareness with the legal consciousness of the society. It happens not only, and, mostly, not so much as by oppressing the individual's own mindsets and passive assimilation to the collective requirements (though it also takes place as a certain stage in building relations with the society), as by means of sophisticated transfusion of interests, legal values of the state on one hand and the personality on the other.

The transfusion and corresponding reconstruction of the social values and legal mindsets inevitable in the process of assimilation in a new social medium constitutes the core of the legal awareness of a citizen. Searching for the optimal way to achieve the objectives of their activity, the citizen becomes more active and more advanced in finding their way in the system of organizational and regulative relations.

Establishment of an individual's legal consciousness is predetermined by the social relations system and the historically determined medium. It means that, being an external factor for the individual, the system of regulations makes an impact on them by means of internal conditions which are psychological features and traits of their personality. The efficiency of this impact is generally determined not by the regulations, regulatory organizational and legal relations themselves acting as stand-alone and independent causes, but first of all by the reasons refracting their inner world through the prism of the conditions and specific characteristics of the surrounding world [1].

M. Deliagin fairly emphasizes that “... corruption makes the impression of the fundament of the current political system and, no doubt, of the wealth of the ruling class. Development of the country is blocked because, if announced to be the real priority, the financial flows will divert their courses to be "shared" by other people, leaving the most powerful part of today's ruling bureaucracy with no work or money" $[4$, p. 151]. The core and the level of development of a citizen's legal consciousness mainly depends on the fact that in the course of their active and dynamic attitude to the social medium, the citizen can learn from it and recognize social, ethical and legal benchmarks for their activity. Moreover, together with the standards and aspects of social legal behaviour the citizen faces in the process of interaction with the society, they also learn the values unrelated to the closest surrounding or labour collective. Diverse in its structure, the social surrounding sets contradictory, conflicting requirements for the individual. In such situations at the absence of the individual's life experience, ability for critical analysis, adequate evaluation of their own deeds, they find themselves unable 
to confront the possible negative influence [13]. The role of such negative influence can be played by corruption which can make a serious impact on social relations within a certain society, which is absolutely valid for modern Russia as well.

The only real counteraction against corruption is a healthy everyday life of a collective of individuals, filled with great spiritual sense and positive social intentions. It is explained by the fact that a society can successfully perform its positive incentive function to make an impact on the legal consciousness of its members, shaping firm social and legal position in their minds. The process connected with acceptance of an individual into the collective, and assimilation to the conditions of the collective bears significant meaning in forming the corruption-proof legal awareness of the citizen.

For productive war on corruption in modern Russia a special significance is borne by studies of the following issues:

1) principles of organizing and functioning of legal information in Russian society, interaction between different means of legal information and their efficiency;

perception and interpretation of legal information in various social strata, professional groups; proportion of the legal information functioning in the collective to the information provided by the corresponding institutes; search for the optimal convergence of the two types of information and efficiency of the influence made by information on human consciousness;

3) search for the optimal volume and content of legal information targeted at different social strata, including youth.

The character and peculiarities of forming legal consciousness in the society in the process of personal adaptation make deliberate influence on the process especially necessary, with the anticorruption measures playing the principal role in the process.
Being its spiritual base, the consciousness of each stand-alone individual and different aspects of the consciousness participate in forming and manifesting civil individuality, as without the awareness of the material world, oneself, one's deeds and attitude to the surrounding world civil individuality is out of question. Making an impact on the consciousness of a citizen, we thereby make an impact on their individuality, shaping it in the way required by the society. In its turn, expressing the interests of the society, social consciousness sets the general requirements and deliberate forms of social forming of the civil individuality determined by the existing social relations. "The major task is forming fair competition in the relationship between the business and the state. The mechanisms of partnership between private business and the state must not turn into symbiosis of corrupt bureaucracy and oligarch business. To achieve it, we need to provide transparent, equal and competitive conditions of access to all kinds of the state resources: government procurement, subsidies, licensing etc.” [3, p. 108]. The way the collective consciousness forms civil individuality depends on the correspondence of the collective consciousness to the universal standards and requirements for human individuality. However, it is important to bear in mind that at the present time globalization is developing through deteriorating the human nature; for this reason, it is first required to turn it back to the humanistic course and orient it to the construction of the future global community with the dominating role of sociocultural service [14, p. 231].

The peculiarity of studying corruption as a modern phenomenon is the necessity for close integration of scholars of different types. It can be only possible under the conditions of allnation unity in appraisal of the strategic tasks of the country as a whole. In the modern period distinctive for its unusual dynamism there are various deformations of legal awareness that take 
place, requiring profound research and attention. Legal awareness studies are also relevant for the unstable, vague and controllable nature of legal awareness.

Therefore, we can conclude that the presence of appropriate social conditions may act as the basis for both corrupt consciousness formation and counteraction against it, creation of an uncompromising anticorruption climate, thereby forming the new relationships within the corruption-proof generation.

\section{References}

1. Valitskiy A.V. Nravstvennost' i pravo v teoriiakh russkikh liberalov kontsa XIX-nachala $X X$ veka [Ethics And The Right In The Theories Of Russian Liberals Of Late $19^{\text {th }}$-Early $20^{\text {th }}$ Centuries] // Voprosy filosofii. 1991, No.8.

2. Hegel H. Filosofiia prava [Philosophy Of Right] // Collection of works. Vol. VII. Moscow: Politizdat, 934. 294 p.

3. Glaz'ev S. Kak sovershit' ryvok [How To Perform A Breakthrough] // Odnako. December 2013-January 2014. P. 108.

4. Deliagin M.G. Pomeniaem oslov na koney [Let's Exchange Asses For Horses] // Odnako. December, 2013-January, 2014. P. 151.

5. Il'in I.A. O suschnosti pravosoznaniia [On The Essence Of Legal Awareness]. Moscow: Rarog, 1993. $196 \mathrm{p}$.

6. Kaminskaia V.I., Ratinov A.R. Pravosoznanie kak element pravovoy kul'tury [Legal Awareness As An Element Of Legal Culture] // Pravovaia kul'tura i voprosy pravovogo vospitaniia. Moscow, 1974.

7. Lorenz K. Ob agressii [On Aggression] // Voyna i geopolitika. Vol. 3 of Vremia Mira almanac. Edited by N.S. Rozov. Novosibirsk, Novosibirsk State University, 2013. P. 20.

8. Lukasheva E.A. Sotsialisticheskoe pravosoznanie i zakonnost' [Socialistic Legal Awareness And Legitimacy]. Moscow, Progress, 1973, P.48.

9. Mel'nikova T.V. Osnovnye tipy obschestva i pravosoznanie [Main Types Of Society And Legal Awareness]. Krasnoyarsk, SAA, 2001.

10. Nersesiants V.S. Obschaia teoriia prava i gosudarstva [General Theory Of Right And State]: college textbook. Moscow: Norma, 2000. 357 p.

11. Nersesiants V.S. Filosofiia prava [Philosophy Of Right]: college textbook. Academic Legal University of the Institute of State and Right of Russian Academy of Science. Moscow: NORMAINFRA. 1998, 384 p.

12. Rabinovich P.M. Pravo kak iavlenie obschestvennogo soznaniia [Right As A Collective Consciousness Phenomenon] // Pravovedenie. 1972. No.2, P. 104-116.

13. Tumanov V.A. Ucheniia o prave [Theories Of Right] // General Theory Of Right: lecture course / edited by V.K. Babaev. Nizhny Novgorod: Bukva, 1993.

14. Iatsenko M.P. Globalizatsiia kak forma istoricheskogo protsessa $i$ axiologiia istorii [Globalization As A Form Of Historical Process And Axiology Of History] // Nauchnye problemy gumanitarnykh issledovaniy. Scientific journal. Volume 9. Pyatigorsk, 2010. P. 231. 


\title{
Коррупция как трансформация правового сознания (социально-философский аспект)
}

\author{
C.В. Кузь \\ Сибирский федеральный университет \\ Россия, 660041, Красноярск, пр. Свободный, 79
}

\begin{abstract}
Актуальность данной статьи связана с тем фактом, что коррупџия становится насущной проблемой не только в правовом ракурсе, поскольку начинает принципиально угрожать безопасности страны. Автор доказывает, что исследование сущности истоков коррупиии невозможно без учета сочиально-философского фактора.

В статье раскрываются соииально-философские истоки возникновения коррупционных деяний. Автор в своем исследовании особо останавливается на особенностях коррупиионного сознания в России. Он доказывает, что подобные антисоииальные действия связаны с трансформацией правового сознания, что имеет в России исторические корни. Вместе с тем в статье показаны пути снижения проблемы коррупции, что во многом детерминировано повышением правовой культуры граждан России.

В статье акиентируется внимание на том факте, что для эффективной борьбы с коррупцией на высоком уровне правовой техники, важно их точное, неуклонное осуществление, ведь любой закон живет только тогда, когда он осуществляется всеми и повсеместно. Именно поэтому даже отдельные случаи коррупци ставят под сомнение сам принцип правового государства.
\end{abstract}

Коррупиия также обусловлена тем, что специфичность связи каждой из форм общественного сознания с правом отнюдь не означает отсутствия общих для них путей и способов взаимодействия, позволяющих говорить о соотношении общественного сознания в единстве различных форм с правом, законностью.

Для анализа особенностей коррупиионного мылления и поведения в нашей стране принципиальное значение принимает дискуссия отипахобщества, необходимая для выявления специфики теоретизирования, учитывающего особенности каждого соииального типа. Необходимость выделения и различения типов общества обусловлена также социальной практикой, когда в современной российской действительности навязывается доминирование положительно зарекомендовавших себя в условиях западного образа жизни духовных и социальных иенностей при одновременном принижении и пренебрежении отечественного соииального опыта.

Исследуя коррупичю, важно учитывать, что взаимодействие гражданина с новой для него соииальной средой осуществляется при постоянном обращении его к своим знаниям, прошлому опыту соииально-правового поведения. Причем этот процесс сопровождается постоянным анализом новых для него требований коллектива, сравнением их со сложившимися у него прежними представлениями и установками на этот счет. Правовое сознание гражданина по своему содержанию может находиться на одном уровне измерений с сознанием коллектива, но может и существенно расходиться.

Реальным противодействием коррупиии может выступать повседневная жизнь коллектива граждан, потому что она наполнена большим духовным смыслом, позитивной социальной направленностью. Это связано с тем фактом, что коллектив успешно может выполнять свою функиию положительно направленного воздействия на правовое сознание члена данного коллектива, формируя у гражданина стойкие соииально-правовые убеждения.

Автор приходит к выводу, что наличие соответствующих сочиальных условий может выстуупать базисом как для формирования коррупиионного сознания, так и противодействия ему, создания непримиримого антикоррупчионного климата, что на уровне конкретного поколения поможет сформировать новые отномения, где не будет места коррупиии. 
Ключевые слова: коррупция, правовое сознание, трансформации правового сознания, институализация общественной жизни, сочиальный контроль, гражданское общество.

Научная спеииальность: 09.00.00 - философские науки. 